\title{
KEDUDUKAN HUKUM PIDANA ATAS PENGAMBILAN KENDARAAN PAKSA DEBITUR OLEH DEBT COLLECTOR LEMBAGA PEMBIAYAAN
}

Oleh :

\author{
Imaculata Sherly Mayasari \\ Email : sherly.data36@gmail.com \\ Universitas Narotama Surabaya \\ Nynda Fatmawati Octarina \\ Email : nynda_f@yahoo.com \\ Universitas Narotama Surabaya
}

\begin{abstract}
Abstrak
Penggunaan Debt Collector pada perusahaan pembiayaan konsumen tidak dilarang asal dilaksanakan sesuai dengan prosedur yang ditetapkan dan tidak melanggar norma serta aturan yang ada. Akan tetapi pada prakteknya, para debt collector sering tidak beretika ketika menarik kendaraan milik debitur yang menunggak. Karena tugas mereka hanyalah menagih hutang bukan untuk menakuti, menyiksa apalagi berbuat yg sampai menghilangkan nyawa orang lain. Oleh karena itu, masyarakat agar mematuhi kontrak yang sudah dibuat kepada satu perusahaan pembiayaan konsumen dan pada debt collector agar tidak bertindak melanggar hukum dalam melaksanakan tugas-tugasnya.
\end{abstract}

Kata Kunci : Debt Collector, Lembaga Pembiayaan, Penarikan Sepeda Motor

\begin{abstract}
The use of a Debt Collector in consumer finance companies is not prohibited as long as it is carried out in accordance with prescribed procedures and does not violate existing norms and regulations. However, in practice, debt collectors are often unethical when pulling vehicles belonging to delinquent debtors. Because their job is just a debt debt, not to fear, let alone taxes that have taken the lives of others. Therefore, the public must comply with the contracts that have been made with a consumer finance company and to a debt collector so as not to violate the law in carrying out their duties.
\end{abstract}

Keywords : Debt Collector, Financing Institution, Motorcycle Withdrawal 


\section{PENDAHULUAN}

\subsection{Latar Belakang}

Pada era globalisasi sekarang ini, masyarakat berkembang sangat cepat. Batas-batas ataupun jarak di dunia sudah tidak berpengaruh dengan adanya teknologi internet. Dalam segi ekonomi juga mengalami perkembangan yang sangat cepat dan juga menuntut kecepatan mobilitas bagi masyarakat yang terlibat di dalamnya. ${ }^{1}$ Salah satu hal yang mendukung kecepatan dalam mobilitas masyarakat adalah kendaraan bermotor. Secara umum jenis kendaraan bermotor yang nantinya bisa produknya bisa terjual dan mendapatkan keuntungan dari masyarakat.

Inovasi produk kendaraan bermotor dari waktu ke waktu telah mengalami kemajuan yang sangat pesat. Maka para produsen sepeda motor berlomba-lomba menciptakan inovasi produk terbaru sepeda motor dengan berbagai macam inovasi tebaru serta para produsen sepeda motor semakin meningkatkan kapasitas produksinya. Hal ini juga turut dipengaruhi oleh gencarnya iklan produk sepeda motor baru dari para produsen yang dibuat sedemikian menarik minat masyarakat untuk membelinya.

Gencarnya penawaran produk sepeda motor mengakibatkan tingginya minat

\footnotetext{
1 Sunaryo, Hukum Lembaga Pembiayaan, Jakarta : Sinar Grafika, 2008, hlm.99
}

masyarakat untuk membeli sepeda motor. Hal ini juga didukung dengan kemudahan yang ditawarkan oleh para produsen dalam menarik minat pembeli, pembeli tidak harus membayar lunas pembelian sepeda motor, namun bisa juga dengan cara mencicil setiap bulannya (kredit) hingga jangka waktu tertentu. Para produsen sepeda motor bekerja sama dengan leasing atau lembaga pembiayaan. Leasing atau lembaga pembiayaan Adira Finance, FIF, WOM, BAF, Suzuki Finance, Sasana Artha Finance, CS Finance, Summit Finance, dan lain sebagainya yang umumnya bekerja sama dengan produsen (dealer) sepada motor dimana pada tahap selanjutnya leasing atau lembaga pembiayaan tersebut yang akan membiayai pembeliaan kendaraan sepeda motor konsumen.

Pihak lembaga pembiayaan bekerjasama dengan Jasa Debt Collector dalam hal penagihan ketika debitur tersebut tidak membayar sesuai dengan apa yang di perjanjikan. Jasa debt collector memang digunakan oleh hampir seluruh bank-bank yang memberikan fasilitas kredit kepada nasabahnya agar segera melunasi pembayaran kredit yang diberikan bank tersebut. Batasan debt collector pun sering kali dipertanyakan, karena pada faktanya banyak hal yang dikaitkan dengan ancaman dan kekerasan. Meski belum ada ketentuan hukum yang secara khusus mengatur apa 
batasan tindakan debt collector ini. Namun, dalam Pasal 9 ayat (1) PBI No. 11/11/PBI/ 2009 dan Pasal 37 PBI No. 14/02/PBI/2012 jasa debt collector yang tidak memenuhi ketentuan dapat dikenakan sanksi administratif.

Pada prosesnya, dalam praktik di lapangan masih saja kerap kali terjadi adanya debt collector untuk melakukan pengambilan atau penarikan sepeda motor sebagai objek kredit yang kreditnya macet karena kurang pahamnya debitur sehingga banyak debitur yang pasrah untuk disita sepeda motornya. Banyak lembaga pembiayaan menggunakan isi perjanjian sebagai dasar untuk menarik barang sebagai objek perjanjian pembiayaan tersebut. Berdasarkan pada uraian di atas, tulisan ini hendak membahas mengenai kedudukan kreditur terhadapl objek jaminan fidusia yang belum terbagi karena perceraian.

\subsection{Rumusan Masalah}

Berdasarkan latar belakang yang telah dipaparkan di atas, maka permasalahan yang akan diteliti dapat dirumuskan sebagai berikut :

1. Apakah tindakan pengambilan paksa atas barang orang lain oleh Debt Collector dapat dikatakan sebagai tindak pidana?

2. Bagaimanakah bentuk pertanggung jawaban debt collector atas tindakan penarikan paksa sepeda motor yang menjadi obyek kredit?

\section{METODE PENELITIAN}

Penelitian ini menggunakan metode penelitian hukum normatif, yaitu meneliti hukum dari perspektif internal dengan objek penelitiannya adalah norma hukum. Dengan kata lain penelitian hukum yang meletakkan hukum sebagai sebuah bangunan sistem norma. Sistem norma yang dimaksud adalah mengenai asas-asas, norma, kaidah dari peraturan perundangan, putusan pengadilan, perjanjian serta doktrin (ajaran). ${ }^{2}$

Pendekatan yang digunakan adalah pendekatan perundang-undangan dan pendekatan konseptual. Pendekatan perundangundangan atau statute approach digunakan jika permasalahan penelitiannya mempermasalahkan konflik norma yang terjadi secara vertikal maupun horizontal. Misalnya norma yang berada pada sebuah peraturan perundang-undangan yang bersifat khusus atau umum, ataukah berada pada yang lebih tinggi atau lebih rendah, dan berada pada yang lama atau yang baru.

Pendekatan konseptual atau conceptual approach beranjak dari pandanganpandangan dan doktrin-doktrin yang berkembang di dalam ilmu hukum, sehingga

${ }^{2}$ I Made Pasek Diantha, 2016, Metodologi Penelitian Hukum Normatif dalam Justifikasi Teori Hukum, Prenada Media Grup, Jakarta, hlm.12 
dapat menemukan ide-ide yang melahirkan pengertian-pengertian hukum, konsepkonsep hukum, dan asas-asas hukum yang relevan dengan isu yang dihadapi. ${ }^{3}$

\section{HASIL DAN PEMBAHASAN}

\subsection{Tindakan Pengambilan Paksa Atas} Barang Orang Lain Oleh Debt

\section{Collector Sebagai Tindak Pidana}

Maraknya kasus pemaksaan dan penganiayaan yang dilakukan oleh debt collector terhadap konsumen yang mengalami kredit macet dalam hal pembayaran ke lembaga pembiayaan yang dilakukan dengan cara mengangsur / mencicil debt collector terhadap nasabah kredit macet. Penarikan atau perampasan motor kreditan tidak hanya terjadi di rumah-rumah nasabah dan tidak jarang debt collector bertindak sebagai pelaku kejahatan dalam penarikan kredit saat dikendarai nasabah di jalanan.

Kredit bermasalah adalah kredit dengan kolektibilitas macet atau kredit yang memiliki kolektibilitas diragukan yang mempunyai potensi macet. Subarjo Joyosumarto (1994) merumuskan kredit macet itu sebagai berikut: ${ }^{4}$

a. Kredit yang angsuran pokok dan bunganya tidak dapat dilunasi selama lebih

\footnotetext{
${ }^{3} \mathrm{Ibid}, \mathrm{hlm} .159$

${ }^{4}$ Uswatun Hasanah, Hukum Perbankan, Setara, Malang, 2017, hlm. 72-73
}

dari 2 masa angsuran ditambah 21 bulan; dan

b. Penyelesaiannya telah diserahkan kepada pengadilan / BUPLN ; atau

c. Penyelesaiannya telah diajukan ganti kerugian kepada perusahaan asuransi kredit ;

Masalah yang terjadi ketika kredit bermasalah atau kredit macet yang mana merupakan resiko yang terkandung dalam setiap pemberian kredit oleh perusahaan. Resiko tersebut adalah nasabah mengalami kesulitan untuk memenuhi kewajibannya untuk mengembalikan kredit tepat pada waktunya. Ketidakmampuan nasabah membayar utangnya (kredit) berdampak negatif kepada para perusahaan sebagai penyalur kredit. Sebaik apapun analisis kredit yang dilakukan dalam mempertimbangkan permohonan kredit, kemungkinan terjadinya pemberian kredit bermasalah tetap akan ada.

Menurut Peraturan Menteri Keuangan bagi perusahaan pembiayaan pihak leasing tidak dapat mengambil kendaraan secara paksa. Hal itu tertuang dalam Pasal 3 Peraturan Menteri Keuangan (PMK) No.130/PMK.010/ 2012 tentang pendaftaran Fidusia bagi perusahaan pembiayaan: "Perusahaan pembiayaan dilarang melakukan penarikan benda jaminan fudisia berupa kendaraan bermotor apabila Pendaftaran Fidusia belum menerbitkan sertifikat jami- 
nan fidusia dan menyerahkannya kepada Perusahaan Pembiayaan”.

Menurut Sentosa Sembiring pengertian dari bank adalah suatu badan usaha yang berbadan hukum yang bergerak di bidang jasa keuangan, yang dapat penghimpunan dana dari masyarakat secara langsung dan menyalurkan kembali ke masyarakat melalui pranata hukum pengkreditan. ${ }^{5}$

Dari penjelasan tersebut, dapat kita pahami bahwa bank merupakan subjek hukum yang berbentuk badan hukum. Oleh karena itu sifat hukum perbankan kita merupakan hukum memaksa, artinya bank dalam menjalankan usahanya harus tunduk dan patuh terhadap aturan-aturan yang telah ditetapkan dalam undang-undang. Dalam hal ini memberi hak menggugat atau menuntut bagi masyarakat terutama nasabah jika merasa dirugikan dalam menerima pelayanan dari bank, karena mempunyai hak dan kewajiban, dan dapat digugat dan menggugat di muka pengadilan.

Namun demikian dalam praktik di lapangan masih saja kerap kali terjadi adanya debt collector untuk melakukan pengambilan atau penarikan sepeda motor sebagai objek kredit yang kreditnya macet karena kurang pahamnya debitur sehingga banyak debitur yang pasrah untuk disita sepeda motornya.

\footnotetext{
${ }^{5}$ Ibid, hlm. 79
}

Banyak lembaga pembiayaan menggunakan isi perjanjian sebagai dasar untuk menarik barang sebagai objek perjanjian pembiayaan tersebut, maka Untuk mengamankan pelaksanaan eksekusi jaminan Fidusia, POLRI menerbitkan Peraturan Kapolri No. 8 tahun 2011 yang berlaku sejak 22 Juni 2011. Tujuan diterbitkannya Peraturan Kapolri No.8 Tahun 2011 adalah untuk menyelenggarakan pelaksanaan eksekusi jaminan fidusia secara aman, tertib, lancar, dan dapat dipertanggungjawabkan; melindungi keselamatan Penerima Jaminan Fidusia, Pemberi Jaminan Fidusia, dan/atau masyarakat dari perbuatan yang dapat menimbulkan kerugian harta benda dan/atau keselamatan jiwa.

Suatu hubungan hutang-piutang antara nasabah dengan kreditur (penjual dan pembeli, atau penerima kredit dan bank) umumnya diawali dengan perjanjian. Seorang pembeli sepeda motor secara kredit adalah nasabah yang melakukan perjanjian jualbeli dengan dealer-nya sebagai kreditur. Jika nasabah wanprestasi tidak melaksanakan kewajiban melunasi kredit maka berdasarkan alasan syarat batal kreditur dapat membatalkan perjanjian. Dengan batalnya perjanjian maka kreditur dapat menarik kembali barang-barang yang telah diserahkannya kepada nasabah.

Namun pengambilan barang oleh debt collector tidak dapat diambil dengan cara semena-mena, melainkan harus mengikuti 
prosedur yang ada dan sesuai dengan peraturan Kementrian Keuangan No. 10 tahun 2012. Kenyataan yang terjadi di masyarakat, dimana oknum debt collector sering melakukan penyitaan yang tidak sesuai dengan SOP mengakibatkan oknum tersebut dapat dikategorikan sebagai suatu perbuatan tindak pidana yang dalam hal ini adalah pencurian.

Berikut beberapa hal yang harus dipahami masyarakat mengenai prosedur penarikan kendaraan bermotor dari debitur oleh perusahaan pembiayaan: ${ }^{6}$

1. Debitur perlu memastikan bahwa proses eksekusi benda jaminan fidusia telah sesuai dengan prosedur yang diatur dalam perjanjian pembiayaan, termasuk mengenai tahapan pemberian surat peringatan kepada debitur/konsumen

2. Petugas yang melakukan eksekusi benda jaminan fidusia merupakan pegawai perusahaan pembiayaan atau pegawai alih daya perusahaan pembiayaan yang memiliki surat tugas untuk melakukan eksekusi benda jaminan fidusia.

3. Petugas yang melakukan eksekusi benda jaminan fidusia membawa sertifikat jaminan fidusia

4. Proses penjualan barang hasil eksekusi benda jaminan fidusia harus dilaksana-

\footnotetext{
${ }^{6}$ http://finansial.bisnis.com/read/20180104/89/72336 1/prosedur-penarikan-kendaraan-ini-hal-yangperlu-dicermati-nasabah (diakses tanggal 17 Agustus 2020)
}

kan sesuai dengan ketentuan peraturan perundangan mengenai jaminan fidusia Interaksi yang diinginkan oleh debt collector sebenarnya ingin mendapat tagihan yang maksimal dan begitu debitur menginginkan dari debt collector adanya pemahaman dengan kondisi nasabah yang sebenarnya. Ketika didalam interaksi tidak adanya saling pemahaman dari kedua belak pihak maka interaksi tersebut tidak akan sesuai dengan apa yang diinginkan. Hasil dari interaksi yang tidak sesuai tersebut maka akan terjadi suatu konflik di dalam interaksi tersebut.

Konsep yang dikemukakan oleh Homanas ini mengandung pengertian bahwa interaksi adalah suatu tindakan yang dilakukan oleh seseorang dalam interaksi merupakan suatu stimulus bagi tindakan individu lain yang menjadi pasangannya. ${ }^{7}$

Perilaku debt collector saat ini masih menjadi masalah serius yang belum ada penanganannya. Tindakan menyita paksa barang oleh kreditur dan debt collector-nya adalah pelanggaran hukum maka tindakan itu dapat berindikasi tindak pidana pencurian mengambil barang yang sebagian atau seluruhnya milik orang lain secara melawan hukum. Atas pelanggaran hukum tersebut, pembeli sepeda motor berhak melaporkannya kepada polisi. Perbuatan debt collector tersebut dapat dijerat dengan

7 D. Hendropuspito OC, Sosiologi Sistematik, Kanisius, Jakarta, 1989, hlm. 14 
Pasal 362 Kitab Undang-Undang Hukum Pidana KUHP tentang pencurian atau jika dilakukan dengan kekerasan atau ancaman kekerasan maka bisa dijerat dengan Pasal 365 ayat (1) KUHP.

Sanksi Pidana adalah suatu hukuman sebab akibat, sebab adalah kasusnya dan akibat adalah hukumnya, orang yang terkena akibat akan memperoleh sanksi baik masuk penjara ataupun terkena hukuman lain dari pihak berwajib. Sanksi pidana pada dasarnya merupakan suatu penjamin untuk merehabilitasi perilaku dari pelaku kejahatan tersebut, namun tidak jarang bahwa sanksi pidana diciptakan sebagai suatu ancaman dari kebebasan manusia itu sendiri

\subsection{Bentuk Tanggung Jawab Debt}

Collector Atas Tindakan Penarikan

Paksa Sepeda Motor yang Menjadi Obyek Perjanjian Kredit

Akibat hukum debitur wanprestasi pada perusahaan lembaga pembiayaan konsumen adalah kreditur tidak mendapatkan pemenuhan hak-haknya yang semestinya didapatkan dengan adanya perjanjian tersebut. Hal ini terjadi karena hubungan hukum yang terjadi antara debitur dengan perusahaan pembiayaan didasarkan pada adanya sebuah perjanjian yakni perjanjian pembiayaan konsumen.

Secara yuridis, akibat hukum dari wanprestasi dalam suatu perjanjian tidaklah sesederhana itu. Sebab perjanjian sebagai ikatan dalam bidang hukum perdata antara dua subjek hukum atau lebih, dimana satu pihak berhak atas sesuatu dan pihak yang lainnya berkewajiban untuk melakukannya.

Bahwa terdapat beberapa permasalahan yang timbul dalam pelaksanaan perjanjian pembiayaan konsumen, yaitu sebagai berikut $:^{8}$

1. Debitur tidak memenuhi salah satu kewajibannya yang ditentukan dalam perjanjian, yakni tidak membayar angsuran dengan lewatnya waktu 30 (tiga puluh) hari sejak tanggal jatuh temponya angsuran;

2. Debitur tidak menjaga dan merawat barang jaminan yakni sepeda motor dari kemungkinan rusak atau hilang.

3. Debitur menjual, meminjamkan, atau melakukan hal-hal lain yang menyebabkan beralihnya sepeda motor kepada pihak ketiga dengan bentuk dan cara apapun tanpa sepengetahuan pihak kreditur, seperti misalnya sepeda motor biasanya diperuntukkan untuk orang lain dimana jika suatu saat orang yang menggunakan sepeda motor tersebut hilang bersama dengan sepeda motornya maka atas nama kredit biasanya tidak mau bertanggung jawab terhadap angsurannya.

${ }^{8}$ Muchtar Masrudi., Debt Collector Dalam Optik Kebijakan Hukum Pidana, Aswaja Presindo, Yogyakarta, 2013, hlm. 103 
Untuk penyelesaian wanprestasi pada lembaga pembiayaan, debitur pertama-tama akan disomasi atau diberikan SP (Surat Peringatan) oleh collector, dimana masingmasing sebagai berikut : 9

1. Surat Peringatan (SP) 1 diberikan kepada debitur yang terlambat melakukan pembayaran selama 1 bulan atau 30 hari

2. Surat Peringatan (SP) 2 diberikan kepada debitur yang terlambat melakukan pembayaran selama 2 bulan atau 60 hari

3. Surat Peringatan (SP) 3 diberikan kepada debitur yang terlambat melakukan pembayaran selama 3 bulan atau 90 hari.

Jika dalam tenggang waktu 3 bulan atau 90 hari debitur tetap tidak bisa melakukan pembayaran, maka kasusnya akan dilimpahkan ke Divisi PSO (Problem Solving Officer) yaitu divisi penanganan debitur yang terlambat melakukan kewajiban selama 3 bulan keatas. Apabila debitur dalam penanganan PSO tidak juga bisa melakukan pembayaran, maka unit dalam hal ini sepeda motor akan langsung diamankan oleh Divisi PSO. Jika Divisi PSO tidak sanggup melakukan penarikan maka proses penarikannya akan dilakukan oleh Debt

\footnotetext{
${ }^{9}$ Ibid, hlm. 110
}

Collector (DC) yang notabene adalah karyawan eksternal perusahaan (free lance).

Bahwa sampai saat ini belum ada peraturan yang secara khusus mengatur tentang penggunaan jasa debt collector oleh lembaga pembiayaan. Namun penggunaan jasa debt collector sebagai bentuk eksternal collector dimungkinkan oleh pihak lembaga pembiayaan untuk menagih hutang terhadap pihak lain. Dalam hubungan ketenagakerjaan, salah satu perjanjian yang mungkin ada adalah perjanjian kerja. Perjanjian kerja tersebut umumnya memuat kesepakatan antara pekerja dengan perusahaan, yang dalam hal ini sering diwakili oleh manajemen atau direksi perusahaan.

Berdasarkan uraian pada pembahasan permalasana pertama bahwa pengambilan kendaraan bermotor secara paksa dalam perjanjian pembiayaan adalah konsumen telah melakukan wanprestasi (tidak membayar angsuran sesuai yang diperjanjikan), namun apabila kendaraan bermotor sebagai obyek jaminan fidusia tidak didaftarkan oleh perusahaan pembiayaan pada Kantor Fidusia, maka pengambilan paksa tersebut tidak sah, sebab hak kebendaan dari perjanjian fidusia tidak lahir, sehingga perusahaan pembiayaan selaku kreditor tidak dapat menggunakan ketentuan dalam Pasal 29 Undang-Undang Nomor 42 Tahun 1999 tentang Jaminan Fidusia. Seandainya fidusia tersebut didaftarkan sesuai Peraturan Menteri Keuangan (PMK) Nomor 130/ 
PMK.010/2012 dan jika tidak didaftarkan, namun pengambilan kendaraan bermotor (eksekusinya) harus melibatkan aparat kepolisian. Hal ini sesuai dengan Peraturan Kapolri (Perkap) Nomor 8 Tahun 2011 yang menjelaskan bagaimana tata cara pengambilan objek perjanjian kredit yang di atasnya sudah melekat jaminan fidusia, dan sepengetahuan RT/RW setempat.

Tindakan debt collector yang menarik paksa barang, misalnya menarik sepeda motor yang menunggak kredit atau menarik barang-barang di dalam rumah karena belum dapat melunasi hutang pada leasing, merupakan perbuatan melanggar hukum. Tindakan penarikan secara paksa itu ibaratnya menutup lubang masalah dengan masalah yaitu menyelesaikan pelanggaran hukum dengan melanggar hukum yang lebih berat. Seorang debitur yang belum mampu membayar lunas hutangnya (missalnya cicilan kredit sepeda motor yang sudah jatuh tempo) adalah suatu pelanggaran hukum, yaitu melanggar perjanjian. Dalam hal demikian kreditur (leasing) mempunyai hak untuk menarik barang yang telah diserahkan kepada debitur (pembeli sepeda motor) dengan alasan wanprestasi. ${ }^{10}$

Jika kreditur tetap memaksakan diri melakukan penyitaan, maka tindakan tersebut merupakan pelanggaran hukum,

\footnotetext{
${ }^{10}$ Gatot Supramono, Perjanjian Utang Piutang, Kencana Prenada Media Group, Jakarta, 2013, hlm. 89
}

karena tindakan penarikan paksa barang oleh kreditur dan debt collector-nya adalah pelanggaran hukum maka tindakan itu dapat berindikasi tindak pidana pencurian (Pasal 362 KUHP) - mengambil barang yang sebagian atau seluruhnya milik orang lain secara melawan hukum. Atas pelanggaran hukum tersebut, debitur sepeda motor berhak melaporkannya kepada polisi. ${ }^{11}$

Selain pencurian kreditur dan debt collector-nya juga dapat diancam tindak pidana perbuatan tidak menyenangkan kalau sudah emosional dan menggebrakgebrak meja dan tentunya kita sudah dapat membayangkan tindak pidana yang yang lebih kejam lagi jika sang debt collector telah berlagak menjadi jagoan yang gampang main pukul terhadap debitur.

Daripada menggunakan cara-cara kekerasan tersebut ada baiknya pihak leasing dalam menyelesaikan permasalahan kredit macet dapat menggunakan beberapa cara sebagai berikut. Dalam hal terjadi perselisihan ada beberapa cara yang dapat dipakai untuk menyelesaikan perselisihan yang timbul dari kedua belah pihak, yaitu dengan cara sebagai berikut yang diharapkan dapat mencegah premanisme oleh debt collector antara lain :

1. Perdamaian atau negosiasi, arti kata damai disini adalah bahwa antara pihak

\footnotetext{
${ }^{11}$ Saleh, Roeslan, Perbuatan dan Kesalahan Dalam Hukum Pidana, Aksara Baru, Jakarta, 1985., hlm. 99
} 
kreditur dengan pihak debitur atau konsumen mengadakan suatu perdamaia sendiri diluar Pengadilan (non litigasi). Pelaksanaan perdamaian tersebut tergantung dari kedua pihak sehingga terjadilah persetujuan dari kedua belah pihak agar perselihan ini tidak dilanjutkan ke pengadilan. Perlu dijelaskan lebih lanjut bahwa perdamaian yang dilakukan kedua belah pihak diluar pengadilan tersebut hanya berkekuatan sebagai persetujuan kedua belah pihak belaka yang apabila tidak ditaati oleh salah satu pihak maka masih harus diajukan melalui proses di Pengadilan. Jadi persoalannya hanya selesai sementara dan sama sekali tidak dijamin bahwa suatu saat tidak akan terjadi perselihan kembali.

2. Pengadilan, apabila upaya penyelesaian sengketa melalui upaya non litigasi gagal, para pihak dapat mengajukan gugatan ke pengadilan.

Sebaiknya dalam proses penagihan kredit macet, perilaku debt collector dalam penagihan hutang kredit macet harus sesuai aturan hukum yang berlaku di Indonesia. Agar supaya tindakan debt collector dalam menyita unit Jaminan Fidusia (kendaraan bermontor) tidak dikategorikan sebagai suatu perbuatan pidana. Supaya untuk menjamin agar tidak ada lagi tindak pidana yang di lakukan oleh debt collector maka pelaku harus diproses sampai ke tingkat pengadilan dan memaksimalkan vonis pidana penjara dan pidana denda agar mempunyai efek jera terhadap pelaku.

\section{KESIMPULAN}

1. Bahwa Segala macam tindakan debt collector yang mengambil unit jaminan fidusia (unit kendaraan bermontor ) harus mengikuti prosedur yang ada dan sesuai dengan peraturan Kementrian Keuangan No. 10 tahun 2012. Kenyataan yang terjadi di masyarakat, dimana oknum debt collector sering melakukan penagihan kredit bermasalah terhadap nasabah tidak sesuai dengan SOP mengakibatkan oknum debt collector tersebut dapat dikategorikan sebagai suatu perbuatan pidana yang dalam hal ini adalah pencurian ;

2. Bentuk pertanggungjawaban debt collector atas tindakan penarikan paksa sepeda motor yang menjadi obyek kredit debitur dapat mengajukan keberatan kepada perusahaan pembiayaan berdasarkan kesepakatan bersama dalam perjanjian pembiayaan, namun apabila tidak dapat diselesaikan, maka debitur dapat melaporkan pengambilan paksa tersebut dengan dasar pasal perampasan sebagaimana yang disebutkan dalam Kitab Undang 
Undang Hukum Pidana (KUHP). Jadi apabla terjadi pengambilan paksa kendaraan bermotor yang menjadi objek jaminan kredit di tengah jalan, konsumen harus menolak dan dapat melaporkanya kepada pihak kepolisian.

\section{DAFTAR PUSTAKA}

D. Hendropuspito OC, Sosiologi Sistematik, Kanisius, Jakarta, 1989.

I Made Pasek Diantha, Metodologi Penelitian Hukum Normatif dalam Justifikasi Teori Hukum, Prenada Media Grup ,Jakarta, 2016.

Muchtar, Masrudi., Debt Collector Dalam Optik Kebijakan Hukum Pidana, Aswaja Presindo, Yogyakarta, 2013

Saleh, Roeslan, Perbuatan dan Kesalahan Dalam Hukum Pidana, Aksara Baru, Jakarta, 1985.

Gatot Supramono, Perjanjian Utang Piutang, Kencana Prenada Media Group, Jakarta, 2013

Uswatun Hasanah, Hukum Perbankan, Setara, Malang, 2017

\section{PERATURAN PERUNDANG- \\ UNDANGAN :}

Kitab Undang-Undang Hukum Pidana;

Kitab Undang-Undang Hukum Perdata;

Undang-Undang Nomor 42 Tahun 1999 tentang Jaminan Fidusia.

Peraturan Menteri Keuangan (PMK) Nomor 130/PMK.010/2012 Tentang Pendaftaran Jaminan Fidusia ;

Peraturan Kapolri No. 8 tahun 2011 Tentang Eksekusi Jaminan Fidusia ;

\section{INTERNET :}

http://finansial.bisnis.com/read/20180104/8 9/723361/prosedur-penarikankendaraan-ini-hal-yang-perludicermati-nasabah (diakses tanggal 17 Agustus 2020) 


\section{BIODATA SINGKAT PENULIS}

Imaculata Sherly Mayasari, SH., beralamat di Jl. Pandugo Baru XI blok J no 6 Surabaya. Menempuh Pendidikan tinggi sarjana S1 Ilmu Hukum di Fakultas Universitas Kartini Surabaya lulus pada tahun 2005. Pada saat ini tengah menyelesaikan pendidikan pada program Magister Hukum di Fakultas Hukum Universitas Narotama Surabaya. 